\title{
Smart cities and the architecture of security: pastoral power and the scripted design of public space
}

Marc Schuilenburg $^{1 *}$ and Rik Peeters ${ }^{2}$

\begin{abstract}
The architecture of security is often thought of in terms of situational crime prevention and defensible space. In this article, we argue that the emergence of smart cities and smart technology compel a broader conceptualisation of the design of security, which has the potential to transform the governance of our urban landscape. Drawing on the case of the city of Eindhoven's "De-escalate" project-in which sound, smell and lighting programming combined with data analysis is used to reduce violence and aggression in the inner-city entertainment area-we show that the securitisation of urban space can also be pursued by positive triggers for behaviour. The case allows us to rethink the architecture of security in terms of pastoral power-Foucault's notion of governing individuals and populations through care and protection. In sharp contrast with more hostile forms of situational crime prevention and defensible space, which seek to "design out" unwanted behaviour by closing off spaces, pastoral architecture is inclusive and provides "scripts" for desirable behaviour in public space. Moreover, this architecture is incorporated and designed into the existing built environment, operates through psychological triggers rather than physical ones, and is principally developed by private companies rather than the state.
\end{abstract}

Keywords: Smart city, Smart technology, Pastoral power, Architecture, Securitisation

\section{Introduction: architecture of power}

In 1978, construction workers of a new metro line stumbled upon the remains of the main Aztec temple in the heart of Mexico City, which had been buried underneath the colonial city for centuries. Once uncovered, it showed how the Aztecs had extended the temple seven times. Every generation built a higher version on top of the old one in an attempt to please the gods, but also to claim their place in the pantheon of great Mesoamerican civilisations. They modelled the sacred precinct of their city after the lost city of Teotihuacan, better known as "the birthplace of the gods", and used the architecture of their temples for their claim as heirs to the great civilisation before them. Later, the Spaniards went to great lengths to destroy this physical representation of Aztec rule and to erect their own symbols of power in its place.

${ }^{*}$ Correspondence: m.b.schuilenburg@vu.n

${ }^{1}$ VU University, Amsterdam, The Netherlands

Full list of author information is available at the end of the article
They demolished the Aztec temple and used its stones to build a Catholic cathedral. The new temple represented the physical and symbolic destruction of Aztec rule, and the manifestation of a new one.

The history of the Aztec "templo mayor" and the Spanish cathedral exemplify the way we commonly think about "architectures of power": the design of buildings and spaces with the objective to execute, symbolise, or justify authority. In a Foucauldian sense, one of the main functions of architecture is to visualize power and to convey a message by those who built it (Foucault 1977; Sudjic 2011). It tells us something about the (self-proclaimed) importance of an individual, institution or ideology-like the golden Trump Tower in Manhattan or Lenin's Mausoleum, situated in Moscow's Red Square. The architecture of the spectacle remains an important element in the public space of cities across the world as a physical manifestation of "state building" (Minkenberg 2014) and "nation-building" (Vale 1992). But the development of the modern society has, since the seventeenth century, 
also given rise to new manifestations of power through architectures. This development is part of a long history of efforts to control the population through architecture. Foucault was the first to establish a link between the governmentality [gouvernementalité] of the modern state-which became more concerned with monitoring and controlling the population-and the architecture of modern institutions. In Discipline $\mathcal{E}$ Punish, he wrote that "the pomp of sovereignty, the necessarily spectacular manifestations of power, were extinguished one by one in the daily exercise of surveillance" (1977, p. 217). The new form of power was exercised in different structures of confinement. Adapting the model of the Panopticon from Jeremy Bentham, schools, prisons, and factories embraced a disciplinary architecture that aimed to make people productive and efficient through individualisation and training.

In his later lecture series Security, Territory, Population (2009) and The Birth of Biopolitics (2008), Foucault analysed the emergence of the power relation of "security" in liberal and neo-liberal mentalities of rule. Here, rule becomes dependent on ways of "allowing circulations to take place, of controlling them, sifting the good and the bad, ensuring that things are always in movement [...] but in such a way that the inherent dangers of this circulation are cancelled out" $(2009$, p. 65). Although Foucault did not come to a refined analysis of security-he devoted only a few lectures to this concept and scarcely dealt with the question of what it means for the spatial context in which we live-an important element of the new security policies is an architecture that combines the concern for control with the freedom of circulation of both people and things. A well-known example is the nineteenth century urban planning of Paris. Broad avenues, orderly block grids and thoroughfares for modern transport improved traffic circulation, but also allowed government troops free movement to maintain public order at times of riots and other disturbances.

Although much has been written about architectures of sovereign and disciplinary power, little attention has been paid to the architectural revolution of the current securitization process. The focus in safety and security studies during the last two decades has been largely devoted to ways of screening-off places, such as roadblocks, high fences, thick walls, and guarded gateways of urban neighbourhoods and luxury housing complexes (e.g. Davis 1992; Low 2003; De Cauter 2004). Critics of this imperative to control, and the adoption of physical design features to achieve control, have long emphasised that it reduces people's use of public space and the liveliness of urban space. Security is pursued through strategies of exclusion rather than through strategies to improve or strengthen what is already present (Franck 2014).
Although situational crime prevention and the ideas of defensible space (Newman 1972), both rooted in notions of territoriality, are indeed an important element of contemporary urban spaces, we argue that they provide also a limited perspective on what the architecture of security now entails.

In recent years, several authors have emphasised the emergent concept of "positive security" as a means to improve urban safety and security by strategies based on positive attributes of living together, such as "care", "protection", and "belonging". These strategies are less "defensive" in character and focus on inclusion rather than exclusion (e.g. Vale 2005; Schuilenburg et al. 2014). Other scientists have shown how urban space is increasingly used as the playground for smart technologies that both intercept and facilitate the flows of people and things, while gathering information on those flows (e.g. Graham and Marvin 2001; Townsend 2013). Taking stock of both debates, we aim to answer the question: How are architectures of power transformed due to smart technologies and inclusive governmental philosophies?

To answer this question, this article unfolds in four parts. In the first part, we explore the concept of the "smart city" and its underlying assumptions, and show how several urban issues and scientific problems are neglected in the labelling process. In the second part of the article, we demonstrate how the "De-escalate" project in the inner-city entertainment area of the Dutch city Eindhoven expresses new ways of acting and thinking about urban security, as well as how this area is transformed as a result of such practices. In the third part, we examine Foucault's concept of pastoral power to understand how strategies based on positive attributes such as care [cura] are used in the smart design of public space. In the fourth part, we analyse the new architecture of power operating in our smart cities and how this reshapes our identities and our identity categories. In our analysis, we suggest that this architecture of security focuses less on surveillance and exclusion and more on "scripting" the use of public space by designing in new defaults for behaviour.

\section{Exploring the smart city debate}

The term "smart" is the latest urban buzzword to rethink the elementary functions of the modern city. The term "smart city" was first used in the 1990s and has come to dominate urban policy agendas. At that time, the term was coined to signify urban development's turn towards the implementation of new information technologies and how communities could become smart (Alawadhi et al. 2012). The hype surrounding smart cities has been accompanied by a proliferation of attempts to characterise them. Nevertheless, there is still confusion about what a smart city is, especially since similar terms are often 
used interchangeably (Albino et al. 2015). If we google the term "smart city", we find that the word "smart" can refer to a large range of meanings - "intelligent", "knowledge", "creative", "virtual", "instrumented", "interconnected", "digital", amongst others. Although a one-size-fits-all definition of smart city does not exist and definitions posed by particular cities calling themselves "smart cities" lack universality, we can discern different layers in the literature on smart cities. The first layer of smart cities is the use of technology (ICT) to transform and improve life within a city ("smart technology"). The second layer is a human dimension in which people, education, learning and knowledge are the key drivers ("smart people"). The third layer concerns the institutions (policy and governance), which means that partnerships and alliances between public and private stakeholders make decisions and bring smart city initiatives to citizens in real time ("smart governance") (Pardo and Taewoo 2011; Cocchia 2012; Albino et al. 2015).

With the rise of ubiquitous Internet connectivity, the miniaturisation of electronics in such now-common devices as RFID tags, and the use of technology for the design of both personal space (house, car, office) and large-scale urban areas, cities sought to legitimise their use. The legitimisation and the recognition of the smart city rhetoric in interactions between policymaker and citizens are, for the past decade or so, based on four different arguments (e.g. Meijer and Rodríguez Bolívar 2015; Shelton et al. 2015). The most well-known argument concerning the legitimacy of the smart city is that cities are emerging as key sites of social experimentation and problem solving since the majority of the world's population now lives in urban areas and a host of challenges-global warming, natural resource depletion, food and energy insecurity and lingering economic instability-are seriously affecting cities. Barber (2013) has argued that city government is crucial to solving global problems and states that "mayors rule the world". In this context, the smart city promises to offer a means to solve unprecedented urban challenges (Ersoy 2017). This demographic argument is backed by a second argument: smart cities enhance democratic processes. Citizen access to democratic processes such as decision-making and elections can be improved with smart technology. This not only stimulates active citizenship but also enhances the legitimacy of the actions of the municipality in its boroughs.

Smart cities can also be used to foster economic growth. Monitoring, understanding, analysing, and planning the city by leveraging information to make better decisions improves sustainable economic development, equity and quality of life for its citizens, and wise management of natural resources (Batty et al. 2012; IBM 2012). The cornerstone of this argument is that smart technology makes the operation of private enterprises and public institutions and the governance of city life more cost-efficient and opens the door to new businesses and services. The need for efficiency is backed by the assumption that an increasing population puts higher pressure on the urban infrastructure and authorities need to "do more with less" permanently. Rather than being an expense, smart technology creates opportunities for added value in cities and improves the living conditions of its citizens. A final argument highlights the entanglement of smart governance and the potential for perfect and permanent control and surveillance of citizens. The built environment can be designed to reduce vulnerability in many ways: vulnerability from the impacts of global warming, vulnerability from rapid urban growth, vulnerability from ground and water pollution, but most important of all, vulnerability from crime and disorder. A distinctive type of smart architecture can be installed on multiple levels, not only on the scale of global flows of people, goods and information, but also on the scale of squares, streets, and parks - all in order to fight crime and disorder and to provide a greater sense of public security. In this context, smart technology is about gathering big amounts of data and making use of risk assessment systems to predict changes in crime patterns for specific locations, times, and perpetrators (Asquer 2014, p. 20; Bennett Moses and Chan 2016).

An important reason why the smart city has become such a popular device for policy makers and urban planners is the fact that it is presented as a depoliticised concept. Who can be against a smart use of resources and design of the city? Nevertheless, there are some unspoken assumptions and continuing urban problems regarding smart cities. First of all, smart cities promote a neoliberal political economy that prioritises market-led and technological solutions to city governance and development (Hollands 2008; Kitchen 2014; Morozov and Bria 2018). It also automatically leads to the expansion of economic rationality past the economic sphere and into the social sphere. Safe cities, for instance, attract the investments and businesses necessary for economic growth and development. Furthermore, the dominant perception of smart cities as efficient and safe suggests that such a change is inherently positive and neglects more critical urban perspectives on the smart city discourse, as Hollands (2008) rightfully notes, for instance those of Harvey (2005), Davis (1992), Lefebvre (1972) and Castells (1998) on the uneven development of the "urban fabric", "security-obsessed urbanism", the "right to the city" and the "black holes of informational capitalism". As a consequence, it is important to consider how the goals of the smart city-of safety, development, and sustainability-relate to its neoliberal undercurrents as exposed by 
the fact that most of its innovations are market-led and emphasise the need for an efficient and growth-based use of space and resources (including human resources).

In order to shed more light on the question how city life becomes subjugated-through smart architectureto the economic laws of predictability and productivity, we argue for a more historical perspective on how largescale changes in the urban architecture are intertwined with "old" modes of power and knowledge, which open up ways of acting and thinking about ourselves. Technology is not only a tool to perform a particular action, but also the condition in and through which humans live. Viewed in the long run, many of the defining elements of smart architecture are less unique than is often thought. As we will argue, the concept of smart architecture has roots that reach back to the old technique of pastoral power, which originated in early Christianity and in the pre-Christian East in the person of the shepherd. Contrary to sovereign and disciplinary power, pastoral power is a "power of care" (Foucault 2009, p. 127) that aims for the wellbeing of the flock-or the population-by constantly observing and managing daily life. Although pastoral power, smart cities and the architecture of security seem to be incompatible at first sight, it is useful, nonetheless, to gain more insight into the continuity between the activities and operations of pastoral power in the past and the goals of smart architecture in the present. We believe that this continuity is an unjustly neglected theme in present-day discussions about the rise of the smart city and the securitisation of public space. The analysis presented in this article is an attempt to increase our understanding of contemporary changes in the design and use of urban space.

\section{Smart architecture in Eindhoven's night-time economy}

In order to understand the relation between pastoral power and smart architecture, we can take a closer look at the "De-escalate" project in the inner-city entertainment area Stratumseind in the Dutch city of Eindhoven. This project is instructive for the transformative potential of smart technology in the architecture of security in public spaces. Eindhoven, situated in the province of North Brabant in the south of the Netherlands, is one of the largest cities in the Netherlands, with a population of about 223,000, almost a third of whom are of foreign descent. The history of the city of Eindhoven dates back to the thirteenth century, when it was originally known as Eindhoven, literally meaning "End Yards". After gradually growing into an industrial town during the nineteenth century, the city boomed with the rise of the electronics company Philips, which was founded in Eindhoven in 1891. Philips, now one of the largest electronics corporations in the world, attracted and spun off many high-tech companies, helping transform Eindhoven into a major technology hub. While most of Philips' industries have now moved out of the city, about one quarter of the jobs in Eindhoven are still in the technology and ICT sectors. ${ }^{1}$

Statistical resources in the Netherlands show that Eindhoven occupies a top-ranking position in relation to crime and disorder rates. In 2006, 2007, 2009 and 2010, national newspaper AD's annual Crime Barometer ranked Eindhoven as the city with the highest crime rate in the Netherlands. On a national scale, the Netherlands witnessed a strong increase in registered crime, in both quality and degree of seriousness, since the 1960s (Eggen and Van der Heide 2005). However, between 2012 and 2016, registered crime, including violence, burglary and theft, dropped by $20 \%$ in the Netherlands. Last year the police registered a total of 930,000 crimes. Following the national downward trend, safety and security in Eindhoven improved greatly. Nevertheless, the city is still one of the most dangerous cities in the Netherlands to live in, ranking second after Amsterdam according to the aforementioned Crime Barometer.

Local governments in the Netherlands have significant liberties to pursue their own security policies (Prins and Devroe 2017). A notable example is the "De-escalate" project in Eindhoven, which is designed to prevent escalation and defuse aggressive situations. The "Deescalate" project is part of the city's ambition to realise a data-driven urban environment. ${ }^{2}$ The project has a consortium of partners from a wide range of domains, including governmental and commercial partners such as Eindhoven University of Technology, Intelligent Lighting Institute, Municipality of Eindhoven, Philips, Dutch Institute for Technology, Safety \& Security, and Institute of Mental Health Care Eindhoven. The project seeks to complement existing "target hardening" architectural techniques-bars on windows and doors, alarm systems, surveillance cameras, metal detection, et cetera-with an interactive sound, smell and lighting design in the innercity entertainment area Stratumseind. ${ }^{3}$ Startumseind is the longest pub street in the Netherlands and one of the busiest nightlife streets in the Netherlands with more than 50 cafes, bars and nightclubs and attracts some

\footnotetext{
${ }^{1}$ https://www.iamexpat.nl/expat-info/dutch-cities/eindhoven (Accessed: 22 May 2018).

${ }^{2}$ https://www.cbs.nl/en-gb/our-services/innovation/nieuwsberichten/bigdata/statistics-netherlands-city-of-eindhoven-join-forces-to-launch-first -cbs-urban-data-center (Accessed: 22 May 2018).

3 Two real-life situations have been selected to test the dynamic lighting: the entertainment area and a psychiatric care facility. Here, we focus on the application of smart technologies for the design of the public space in the entertainment area.
} 
40,000 visitors every weekend. The kind of behaviour associated with the vibrant area is often loud, aggressive, sometimes violent and frightening.

To combat troublesome behaviour such as violence, aggression, vandalism, rubbish on the streets, public drunkenness and noise disorder in Startumseind, the "De-escalate" project collects anonymous visitor data (up to 15,000 people at the same time) with special measuring equipment that tests the effects of light, smell and sound manipulation on aggression and tension in the area. Lamp-posts have been fitted with wifi-trackers, CCTV-cameras, sensors and microphones that can detect aggressive behaviour and alert police officers to altercations. ${ }^{4}$ The following data is collected and stored by the consortium of public and private partners to profile, nudge or actively target visitors: social interactions, social distance, behaviour, police presence and activity; waste in the street; presence and activity of bouncers at cafes; police reports; sound level; weather information; parking density; beer consumption; people entering and exiting Stratumseind; social media posts; and mobile phone data (including presence of phones and movement patterns). ${ }^{5}$ The collected data is monitored on screens in a control room, located in one of the bars in the entertainment area. The purpose is to de-escalate potential violent conflicts between visitors by changing the intensity and colour of light for instance when the density in the area increases.

Scientific studies show that aggression and escalation are often not intentionally planned but arise because people respond to certain triggers or catalysts in their environment (de Kort et al. 2014). Research also demonstrates that lighting can function as a contextual means to impact the atmosphere of an area and that colours evoke affective responses by visitors. Most of the literature in lighting research emphasises that in dark or dimly lit settings, people tend to release their social inhibitions, more so than they would in brightly lit settings (McAndrew 1993). An effective use of brightness, shape, shine, shadow, silhouette and colour by a lighting engineer can enhance the quality of the urban environment and can reduce incidents occurring in the area. In an interview, a member of the "De-escalate" team stated: "Atmosphere seems to be strongly affecting people's behaviour, including aggression-we are mainly talking about mild forms of aggression, rather than violence. Yet people's

\footnotetext{
${ }^{4}$ https://www.theguardian.com/cities/2018/mar/01/smart-cities-data-priva cy-eindhoven-utrecht (Accessed: 22 May 2018).

5 https://gr1p.org/tag/stratumseind/ (Accessed: 22 May 2018).
}

behaviour by itself is also contributing to the atmosphere. So, it's a vicious circle" (Schuilenburg et al. 2017, p. 47).

The convergence of smart technologies and the design of public space in Eindhoven carves out new ways of thinking about how security is designed into the everyday fabric of urban life. Psychological triggers are used to stimulate an efficient, safe and consumption-focused use of space through architectural interventions that intend to mould the behaviour of the users of that space. Even though the project in Eindhoven, better known as "The Living Lab", is firmly rooted in the securitisation of society by seeking control without stopping or hampering the flow of visitors of Startumseind, it echoes a very different tradition than sovereign and disciplinary examples of surveillance and exclusion, but also marks a departure from the dominant defensive architecture of security. It expresses a vision of social control that strives to make the public space attractive and safe through behavioural interventions towards its users. Following the lead of Foucault's "history of the present", we seek to grasp the power relations underpinning this new way of governing urban security by understanding it as part of the historical development of a pastoral type of power and its gradual assimilation into the secular doctrine of the smart city.

\section{Pastoral power}

The thematic of pastoral power is taken up by Michel Foucault in his lectures Security, Territory, Population (2009) at the Collège de France between 1978 and 1979 and in his Tanner lecture series on human values Omnes et Singulatim (2000a) at Stanford University in 1979. Although Foucault never fully thematises pastoral power, he describes it as being beneficent ("doing good"): it is a benevolent and caring power, which deals with the "the government of souls" (2003, p. 177). This technique of power reaches back to early Christianity and even to pastoral guidance in the pre-Christian East by the person of the shepherd (berger). In Security, Territory, Population, Foucault states that the shepherd not only watches over the herd as a whole, but he also looks after every individual sheep, ensures that the sheep do not suffer, goes looking for animals that have got lost, and treats animals that have been injured (2009, p. 127). Although the theme of the shepherd is also present in Plato's Statesman and some minor references, its core cannot be found in Greek or Roman antiquity. "It is not a Greek nor a Roman idea", writes Foucault in Omnes et Singulatim (2000a, p. 300; 2009, p. 123). The Greek and Roman gods, in being transcendentally distant from human affairs, were never understood as shepherds (Schuilenburg 2015; Elden 2016). 
Foucault describes in Omnes et Singulatim how pastoral power is both an individualising (as opposed to legal power) and a totalising form of power, in that the shepherd (e.g. Yahweh, Christian God, or a human pastor) takes care of the survival of the group as a whole and of every individual sheep. Here, Foucault speaks of the "paradox of the shepherd" (2009, p. 129), namely that because the pastor must care for the multiplicity as a whole [omnes] while at the same time providing for the particular salvation of every individual [singulatim], there must necessarily be both a sacrifice of one for all, and the sacrifice of all for one. The concern with the needs of every separate member depends on a detailed knowledge of each member of the flock. As Foucault notes, "the pastor must really take charge of and observe daily life in order to form a never-ending knowledge of the behaviour and conduct of the members of the flock he supervises" (ibid., p. 181). This implies "a knowledge of the conscience and an ability to direct it" (1983, p. 214). Following a lengthy discussion about the shepherd-flock phenomenon, Foucault states that the pastoral power in its typology, organisation, and mode of functioning, implies a practice that targets "a multiplicity in movement" (2009, p. 125), in order to insert and maintain them in the right path, and to steer their change and development in the appropriate direction.

In the development of a pastoral complex, understood as an assemblage of institutes, techniques, rules, attitudes and beliefs, we can discern at least two parallel paths in play. First, this type of power, which is related to the idea of the shepherd who shields, leads, and protects, has by no means disappeared. Rather, as a technology of power it is continued into the institution of "the Christian Church as a central and learned activity indispensable for the salvation (salut) of all and of each" (ibid., p. 364). Techniques such as self-examination, guidance of conscience, and confession lead to a hermeneutic opinion on, and relation to, the soul. Through a particular discourse of truth, the institutionalisation of the pastoral modality of power makes it possible for individuals to see themselves as a specific subject and to achieve salvation in the next world. Second, the idea of the shepherd underpins the transition from an "economy of souls to the government of men and populations" (ibid., p. 227). In The Subject and Power, Foucault writes that, "we can see the state as a new form of pastoral power" (1983, p. 215). Whereas the function of the pastorate and its institutionalisation in the Christian Church is directed toward individual salvation in the next world, this salvation has now shifted to the care and protection of secular matters in this world such as "health, well-being (that is, sufficient wealth, standard of living), security, protection against incidents" (ibid., p. 215). It is at this point that Foucault introduces the doctrine of police, whose activities entailed more than, "the surveillance of dangerous individuals, expulsion of vagabonds and, if necessary, beggars, and the pursuit of criminals" (2000a, p. 94). Through a reading of German writers of Polizeiwissenschaft and French theorists of police, Foucault describes how policing is about a whole set of techniques that must produce order and is related to matters such as urban hygiene, health, infrastructure, and public security.

As the discussion of pastoral power suggests, the French word for salvation (salut) can mean both "salvation" in its religious sense and "safety" (preserving from harm). In the latter sense, it is directed toward the circumstances under which people live and the risks to which people are exposed. It is not our aim to undertake the history of the pastorate here. Nevertheless, it is important to understand in which way governmentality in its current form builds on the notion of a pastoral power. We suggest, in an extension of Foucault's work, that the use of smart architecture to secure public spaces constitutes signs of a more general transformation towards a reassuring and protective pastoral power. Pursuing security through pastoral techniques is protective, inclusive, preventative, and caring. It does not simply exclude or defend against unwanted behaviour. Instead, it rests on a positive notion of behaviour. Contrary to legal power, it does not merely define the boundaries of what is allowed and desirable, but actively manages the conduct of individuals and the wellbeing of a population within those boundaries. The question is then: "Who will be the pastor-in what form, with what rights, and in order to do what?" (Foucault 2009, p. 149).

\section{Security and the government of souls}

The aforementioned "De-escalation" project in Eindhoven is profoundly pastoral in nature-albeit with a distinctively late-modern twist. It pursues the securitisation of public space not through surveillance and exclusion, but through behavioural manipulation and inclusion. The main objective is to make an urban entertainment area a pleasant place to be for all, not to exclude people from it. The use of light, smell and sound design-soft ways to manage mood and behaviour-stands in sharp contrast with more hostile and defensive forms of security architecture, which seek to "design out" unwanted behaviour without providing cues for alternative behaviour. The "De-escalate" project is constructive in the sense that it seeks to provide incentives or "scripts" for desirable behaviour, which are an integral part of the design of public space in Eindhoven. A "script" is not just the set of directions, it is rather the "designing-in" of "prescriptions" that impose themselves on the visitors in the most direct sense: through light, smell and sound, people's 
mood and-by extension-behaviour is influenced. As we showed, the smart technology works both on an individual and on a collective level: the well-being of the individual visitor-upon whom the techniques directly work-as well as the public safety of the entertainment area.

However, the "De-escalation" project is also different from the kind of pastoral power that Foucault observed in modern liberal states. In Foucault's view, the liberal concern with security not only played out in what we now understand as public safety, but also in the mechanisms of the welfare state, which provided security in terms of care and protection against externalities (Foucault 2000b; see also: Ewald 1986; Dean 1999, ch. 3 and 4). The "Deescalation" project shows that we can think of pastoral power in relation to smart technology, rather than being limited to the mechanisms of solidarity as they were used to construct care and protection in the welfare state. The project thereby also highlights the rapid transformations in the use of technology, algorithms and machine learning in policing and their application for the prediction and prevention of risky behaviour (Bennett Moses and Chan 2016; Smith et al. 2017; Peeters and Schuilenburg 2018). Furthermore, the literature on smart cities and the case in Eindhoven points out that pastoral power is not bound to the "governmentalisation of the state" (Foucault 2009). Instead, private companies with multiple business interests are increasingly playing an important part in urban planning and management. Philips, Google, Uber and IBM, to name just a few, use the urban environment as their laboratory and municipalities tend to give space to all kinds of corporate field experiments, blurring the line between public and private in designing policies and interventions in public space.

The emergence of pastoral techniques in the architecture of security is not an isolated phenomenon. In the field of criminology, scholars have begun to rediscover the positive meanings of the concept security-referring to peace, stability, and community-and identify accompanying governmental techniques that defy our common thinking in terms of security as a "negative" penal power (e.g. Schuilenburg et al. 2014; Van Steden 2017). In economics, scholars have embraced the behavioural revolution that challenges the idea of man as a "homo economicus" that responds rationally to incentives of pain and pleasure and, instead, proposes positive interventions-"nudges", "choice architecture"-that work upon our psychological triggers for daily decision-making (Thaler and Sunstein 2009). In public health, the emergence of welfare diseases has shifted policymaking from protection against externalities to a management of lifestyle that has the mind rather than the body as the object of intervention (Peeters and Schuilenburg 2017). And in social policy, the notion of "responsibilization" (Rose 1996) is increasingly understood in terms of state efforts to manufacture civility and self-efficacy in the margins of the welfare state through 'investment' in vulnerable people (Morel et al. 2012; Juhila et al. 2017). No matter how different these examples may appear at first sight, they have a common basis. Grounded in the literature on the "risk society" (Beck 1986), human action is increasingly seen as an inherent and problematic part of contemporary social problems and, therefore, as a justified object of intervention (Schuilenburg and Peeters 2017). Latemodernity is, in that sense, a pre-eminent era for pastoral power since the wellbeing of everyone is tied up with the wellbeing of every individual and problem-solving depends on positive behavioural notions rather than merely setting (legal) boundaries to human behaviour.

The inclusion of individuals in collective problem-solving plays out differently in various policy domains, but it is clear that smart technology plays an important role in governing behaviour and the design of interventions in public space. In Eindhoven's "De-escalate" project, data on the behaviour of the entertainment area's visitorssuch as the number of people and changes in the collective mood-are collected and stored to identify risks and to manipulate the atmosphere of the area through the use of smart lighting technology. Interestingly, these techniques to extract knowledge about behaviour and subsequently manipulate the behaviour of visitors are an integral part of the design of the urban environment. Consequently, this transforms the way we understand the architecture of power. It shows that pastoral architecture is not tangible but is incorporated in the existing built environment and operates through psychological triggers rather than physical ones... a far cry from the monumental manifestations of power we explored in the introduction of this article.

\section{Conclusion: scripted architecture}

The first things that come to people's minds when they think of smart cities usually involves self-driving vehicles, traffic lights that adjust based on vehicle flow, bike sharing, smart pavements that provide public Wi-Fi access, and talking household devices. Although there are many different definitions of a smart city-the label "smart city" has been applied to completely different urban areas, such as transport, health, energy, housing, education, government, safety and others-it usually involves a combination of human resource ("smart people"), public-private partnerships ("smart collaboration") and emerging technologies ("smart technology"), like internet connectivity, all sorts of sensors, data storage, analytics, visualisation, and mobile solutions. 
In recent years, different smart cities have started to experiment with a technology-based securitisation of public space. Given the fact that this development is becoming a quickly spreading and international phenomenon, we have analysed the use of smart technologies in the Dutch city Eindhoven, which uses smart lighting, smell and sound design in its inner-city entertainment area to combat troublesome behaviour as violence, aggression, vandalism, rubbish on the streets, public drunkenness and noise disorder. As we have shown, the "De-escalation" project pursues the securitisation of public space through a smart architecture that both controls and facilitates the freedom of movement of visitors by using interactive lighting design to manage the atmosphere of the area and to evoke affective responses from visitors. Put differently, instead of forbidding and punishing, it works through pleasing and seducing.

The use of smart technology in the design of public space changes the way we understand the architecture of power. Originally, architectures of power were most visible in monumental structures and symbols that expressed sovereign power. Later, architectures of power became manifest in the panoptic design of disciplinary practices, for instance prisons, factories and hospitals. While both forms of architectural power never disappeared, the smart city is the domain of a different form of architecture: an architecture of security. Architectures of security are often thought in terms of surveillance and exclusion. As Vale observes, "'securing public space' means securing public space from the public, not for it" (2005, p. 41). Perhaps the most controversial manifestation of this architectural policing are "defensive" architecture strategies, in which physical interventions in the public space-for example, anti-homeless spikes-intend to "design out" unwanted behaviour such as loitering and rough sleeping.

However, late-securitisation appears to stress fundamentally different techniques than its earlier manifestations. We argue that the architecture of security is now a "scripted architecture": the design of public space to introduce defaults for desirable behaviour by using non-physical elements of the built environment, such as light, smell and sound. These are experienced through the sensory organs: ears, skin and eyes. The use of public space, as the Eindhoven case study shows, is pre-structured in such a way that the architecture of security anticipates how people will interact with their environment. Here, proper behaviour is encouraged while unwanted behaviour-aggression, violence, vandalism, public drunkenness, noise disorder-is discouraged by the use of techniques of environmental technology or environmental psychology, in order to improve the safety of the entertainment area and the psychophysiological wellness of the individual visitor. The focus in this form of pastoral architecture is on inclusion rather than exclusion, on positive rather than negative incentives, and on psychological mechanisms of behaviour rather than physical deterrence.

Although there is a tendency to see the use of smart technology in urban design as a kind of universal, rational and depoliticised way of intervening in the city, our analysis of the transition of public space from a physical paradigm towards a psychological and behavioural paradigm conveys questions about what, and in which specific ways, smart technology makes things "seeable". As John Rajchman writes, "Architecture helps 'visualise' power in other ways than simply manifesting it. It is not simply a matter of what a building shows 'symbolically' or 'semiotically', but also of what it makes visible about us and within us" (1988, p. 103). If we understand visibility as an organisation of power in both a negative and a positive sense, the use of smart technology and other forms of scripted architecture for the design of the city urges us to reformulate inclusion and exclusion, as well as social practices of rule and identities. Inclusion, for instance, entails more than a mere absence of restraint. Following Foucault's analysis of pastoral power, inclusive approaches to a population are accompanied by very specific ideas about what types of behaviour are desirable and about how the individual should behave in relation to the population he or she is a part of. This point becomes even more pressing when responsibilities relating safety and security issues, previously reserved to public institutions, are delegated to private players, with the goal of establishing a vast arena of perfect and permanent surveillance. As such, the fact that private tech companies are increasingly using public space as their living laboratory to strip out spontaneity and some degree of chaos ("where is the transgression?") is a powerful indicator that new forms of power are emerging-powers that will dramatically change the governance of our urban landscape.

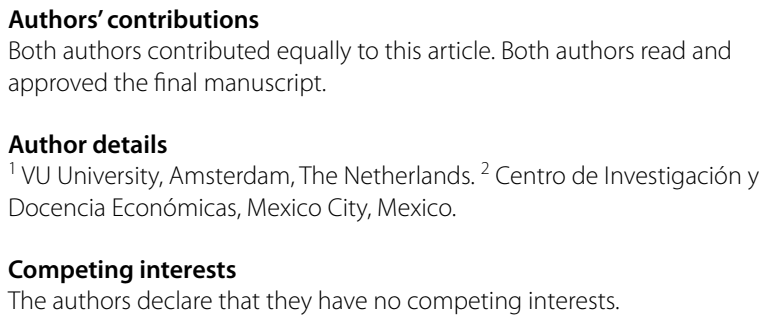

\section{Publisher's Note}

Springer Nature remains neutral with regard to jurisdictional claims in published maps and institutional affiliations.

Received: 1 March 2018 Accepted: 30 May 2018

Published online: 24 October 2018

\section{References}

Alawadhi S, Aldama-Nalda A, Chourabi H, Gil-Garcia JR, Leung S, Mellouli S, Nam T, Pardo TA, Scholl HJ, Walker S (2012) Building understanding of smart city initiatives. Lect Notes Comput Sci 7443:40-53 
Albino V, Berardi U, Dangelico RM (2015) Smart cities: definitions, dimensions, performance, and initiatives. J Urban Technol 22(1):3-21

Asquer A (2014) Big data and innovation in the delivery of public services: the case of predictive policing in kent. In: Dolicanin C et al (eds) Handbook of research on democratic strategies and citizen-centered e-government services. Hersey, Information Science Reference

Barber B (2013) If mayors ruled the world: dysfunctional nations, rising cities. Yale University Press, New Haven

Batty M, Axhausen KW, Giannotti F, Pozdnoukhow A, Bazzani A, Wachowicz M, Ouzounis G, Portugali Y (2012) Smart cities of the future. Eur Phys J 214:481-518

Beck U (1986) Risikogesellschaft: Auf dem Weg in eine andere Moderne. Suhrkamp, Frankfurt am Main

Bennett Moses L, Chan J (2016) Algorithmic prediction in policing: assumptions, evaluation, and accountability. Polic Soc Int J Res Policy. https://doi. org/10.1080/10439463.2016.1253695

Castells M (1998) The information age: economy, society, and culture. End of millennium, vol 3. Blackwell, Oxford

Cocchia A (2012) Smart and digital city: a systematic literature review. In: Dameri R, Rosenthal-Sabroux C (eds) Smart city: how to create public and economic value with high technology in urban space. Springer, Cham

Davis M (1992) City of quartz. Excavating the future in Los Angeles. Vintage, London

de Cauter L (2004) The capsular civilization: on the city in the age of fear. NAipublishers, Rotterdam

Dean M (1999) Governmentality: power and rule in modern society. Sage Publications, London

Eggen AJ, van der Heide W (2005) Criminaliteit en rechtshandhaving 2004: Ontwikkelingen en samenhangen. Ministerie van Justitie/WODC en CBS, The Hague

Elden S (2016) Foucault's last decade. Polity Press, Cambridge

Ersoy A (2017) Smart cities as a mechanism towards a broader understanding of infrastructure interdependencies. Reg Stud Reg Sci 4(1):26-31

Ewald F (1986) L'Etat providence. Grasset, Paris

Foucault M (1977) Discipline and punish: the birth of the prison. Vintage Books, New York

Foucault M (1983) Subject and power. In: Dreyfus LH, Rabinow P (eds) Michel Foucault: beyond structuralism and hermeneutics; with an afterword by Michel Foucault. University of Chicago Press, Chicago, pp 208-226

Foucault M (2000a) "Omnes et Singulatim": toward a critique of political reason. In: Faubion JD (ed) Power. New Press, New York, pp 298-325

Foucault M (2000b) The risks of security. In: Faubion JD (ed) Power. New Press, New York, pp 365-381

Foucault M (2003) Abnormal: lectures at the Collège de France, 1974-1975. Picador, New York

Foucault M (2008) The birth of biopolitics: lectures at the Collège de France, 1978-1979. Palgrave Macmillan, New York

Foucault M (2009) Security, territory, population: lectures at the Collège de France, 1977-1978. Picador, New York

Franck K (2014) Security in support of safety and community. Thoughts from New York. In: Schuilenburg M et al (eds) Positive criminology: reflections on care, belonging and security. Eleven International Publishing, The Hague

Graham S, Marvin S (2001) Splintering urbanism. Networked infrastructures, technological mobilities and the urban condition. Routledge, London

Harvey D (2005) Spaces of neoliberalization: towards a theory of uneven geographical development. Franz Steiner, Stuttgart

Hollands RG (2008) Will the real smart city please stand up? City 12(3):303-320

IBM (2012) How to transform a city: lessons from the IBM smarter cities challenge, IBM Smarter Cities White Paper. https://www.huffingtonpost.com/ steve-hamm/how-to-transform-a-city-l_b_1388504.html. Accessed 19 Oct 2017

Juhila K, Raitakari S, Hall C (eds) (2017) Responsibilisation at the margins of welfare services. Routledge, London

Kitchin R (2014) The real-time city? Big data and smart urbanism. GeoJournal 79(1):1-14
Kort de YAW, IJsselsteijn WA, Haans A, Lakens D, Kalinauskaite I, Schietecat AC (2014) De-escalate: defusing escalating behaviour through the use of interactive light scenarios. In: de Kort YAW, X. et al. (eds.), Proceedings of EXPERIENCING LIGHT 2014: international conference on the effects of light on wellbeing, 10-11 November 2014, Eindhoven, The Netherlands. Eindhoven: Technische Universiteit Eindhoven, pp 94-97

Lefebvre H (1972) Le droit à la ville: Suivi de espace et politique. Anthropos, Paris

Low S (2003) Behind the gates: life, security, and the pursuit of happiness in fortress America. Routledge, New York

McAndrew FT (1993) Environmental psychology. California, Brooks/Cole

Meijer A, Rodríguez Bolívar MP (2015) Governing the smart city: a review of literature on smart urban governance. Int Rev Adm Sci 82(2):392-408

Minkenberg M (2014) Power and architecture: the construction of capitals and the politics of space. Berghahn Books, New York

Morel N, Palier B, Palme J (eds) (2012) Towards a social investment welfare state?: ideas, policies and challenges. The Policy Press, Bristol

Morozov E, Bria F (2018) Rethinking the Smart City. Democratizing urban technology. New York: Rosa Luxemburg Stiftung New York Office. http://www. rosalux-nyc.org/wp-content/files_mf/morozovandbria_eng_final55.pdf

Newman O (1972) Defensible space. Macmillan, New York

Pardo T, Taewoo N (2011) Conceptualizing smart city with dimensions of technology, people, and institutions. In: Proceedings of the 12th annual international conference on digital government research, New York: ACM, pp 282-291

Peeters R, Schuilenburg M (2017) The birth of mindpolitics: understanding nudging in public health policy. Soc Theor Health 15(2):138-159

Peeters R, Schuilenburg M (2018) Machine justice: governing security through the bureaucracy of algorithms. Inf Polity. https://doi.org/10.3233/ ip-180074

Prins R, Devroe E (2017) Local strategies for global challenges. Comparing policing agendas in Amsterdam and Rotterdam. In: Devroe E, Edwards A, Ponsaers P (eds) Policing European metropolises. The politics of security in city-regions. Routledge, New York

Rajchman J (1988) Foucault's art of seeing. October (44), pp 89-117

Rose N (1996) Governing 'advanced'liberal democracies. In: Rose N, Barry A, Osborne T (eds) Foucault and political reason. UCL Press, London, pp 37-64

Schuilenburg M (2015) The securitization of society: crime, risk, and social order. New York University Press, New York

Schuilenburg M, Peeters R (2017) Gift politics: exposure and surveillance in the anthropocene. Crime Law Soc Change 68(5):563-578

Schuilenburg M, van Steden R, Oude Breuil B (2014) Positive criminology: reflections on care, belonging and security. Eleven International Publishing, The Hague

Schuilenburg M, Schoenmakers Y, van Zanten J (2017) Positieve veiligheid. Naar een nieuwe Rotterdamse veiligheidsstrategie. Directie Veiligheid Rotterdam, Rotterdam

Shelton T, Zook M, Wiig A (2015) The 'actually existing smart city'. Camb J Regions Econ Soc 8(1):13-25

Smith GJD, Bennett Moses L, Chan J (2017) The challenges of doing criminology in the Big Data Era: towards a digital and data-driven approach. Br J Criminol 57(2):259-274

Sudjic D (2011) The edifice complex: the architecture of power. Penguin, London

Thaler RH, Sunstein CR (2009) Nudge: improving decisions about health, wealth and happiness. Penguin Books, London

Townsend A (2013) Smart cities. Big Data, civic hackers, and the quest for a New Utopia. Norton \& Company, New York

Vale $L$ (1992) Architecture, power, and national identity. Yale University Press, New Haven

Vale L (2005) Securing public space. Places 17(3):38-42

van Steden R (2017) Street pastors: on security, care and faith in the british night-time economy. Eur J Criminol. https://doi.org/10.1177/1477370817 747499 